\title{
Purification and characterization of TDP-D-glucose 4,6-dehydratase from anthracycline-producing streptomycetes
}

\author{
Mark W. Thompson, ${ }^{1,2} \uparrow$ William R. Strohl ${ }^{2 *}$ and Heinz G. Floss ${ }^{1}$ \\ ${ }^{1}$ Department of Chemistry, University of Washington, Seattle, WA 98195, USA \\ ${ }^{2}$ Department of Microbiology, The Ohio State University, Columbus, OH 43210, USA
}

(Received 3 September 1991; revised 12 November 1991; accepted 5 December 1991)

\begin{abstract}
TDP-D-glucose 4,6-dehydratase, which converts TDP-D-glucose to TDP-D-4-keto-6-deoxyglucose, was purified to near-homogeneity from the daunorubicin and baumycin-producing organism Streptomyces sp. C5 (968-fold purification with a $41 \%$ recovery), and from the daunorubicin producer Streptomyces peucetius ATCC 29050 (1000-fold purification with a $37 \%$ recovery). The TDP-D-glucose 4,6-dehydratases from Streptomyces sp. C5 and $S$. peucetius were determined by SDS-PAGE and HPLC gel filtration to be homodimers with subunit relative molecular masses of 39000 and 36000 , respectively. For the enzymes from both organisms, negligible activity was observed in the absence of added NAD ${ }^{+}$, or when ADP-glucose, ADP-mannose, GDP-mannose, UDP-glucose or UDP-galactose was substituted for TDP-D-glucose as substrate. For the enzyme from Streptomyces sp. C5, the $K_{\mathrm{m}}^{\prime}$ values for NAD ${ }^{+}$and TDP-D-glucose were $19.2 \mu \mathrm{M}$ and $31.3 \mu \mathrm{M}$, respectively. The $V_{\max }^{\prime}$ for TDP-D-glucose was $309 \mathrm{nmol} \mathrm{min}^{-1}$ (mg protein) ${ }^{-1}$. For the $S$. peucetius enzyme, the $K_{\mathrm{m}}^{\prime}$ values for NAD ${ }^{+}$and TDP-D-glucose were $20.1 \mu \mathrm{M}$ and $34.7 \mu \mathrm{M}$, respectively. $V_{\max }^{\prime}$ values were $180 \mathrm{nmol} \mathrm{min}^{-1}$ (mg protein) ${ }^{-1}$ for $\mathrm{NAD}^{+}$and $201 \mathrm{nmol} \mathrm{m^{-1 }}$ (mg protein) ${ }^{-1}$ for TDP-D-glucose. TDP was a good inhibitor of TDP-D-glucose 4,6-dehydratase from both organisms. The $\mathrm{N}$-terminal amino acid sequence of the TDP-D-glucose 4,6-dehydratase from S. peucetius and from the erythromycin producer, Saccharopolyspora erythraea, were similar, whereas the enzyme from Streptomyces sp. C5 contained a different $\mathrm{N}$-terminal amino acid sequence from either of the other two enzymes.
\end{abstract}

\section{Introduction}

Many antibiotics, including macrolides such as tylosin (Matern et al., 1973), erythromycin (Vara \& Hutchinson, 1988), and the avermectins (Schulman et al., 1990), the benzoisochromane quinone, granaticin (Snipes et al., 1979), and anthracyclines such as daunorubicin (daunomycin), doxorubicin (adriamycin), and the aclacinomycins (Fujiwara \& Hoshino, 1983) contain partially deoxygenated hexose sugar components that are usually essential for biological activity. Deoxygenated hexoses in antibiotics commonly lack functionalities at C-2 and C-6, but little detail is known about their mode of formation (Grisebach, 1978; Schulman et al., 1990;

* Author for correspondence. Tel. (614) 2921919 ; fax (614) 2921538.

$\dagger$ Present address: National Institutes of Health, NCI, Bethesda, MD 20892, USA.

Abbreviations: TDPGDH, TDP-D-glucose 4,6-dehydratase; PPB, $\mathrm{KH}_{2} \mathrm{PO}_{4} / \mathrm{K}_{2} \mathrm{HPO}_{4}$ buffer; PVDF, polyvinylidene difluoride; PTH, phenylthiohydantoin; NYDE, nitrate defined yeast extract medium; $\mathrm{ddH}_{2} \mathrm{O}$, double-distilled water; $K_{\mathrm{m}}^{\prime}$, apparent $K_{\mathrm{m}} ; V_{\max }^{\prime}$, apparent $V_{\max }$.
Snipes et al., 1979; Vara \& Hutchinson, 1988). Glucose provides the carbon atoms for 2,6-dideoxyhexoses and other unique hexoses in antibiotics, and the transformations proceed without rearrangement of the carbon skeleton (Grisebach, 1978). The conversion of hexose nucleotides into 4-keto-6-deoxyhexose nucleotides, catalysed by nucleoside hexose 4,6-dehydratases (Gabriel, 1973), is apparently the branch point between normal hexose metabolism and the formation of deoxyhexoses such as L-rhamnose (Glaser \& Kornfeld, 1961). The enzymes have been purified from a variety of sources, including Escherichia coli (Wang \& Gabriel, 1969; Zarkowsky \& Glaser, 1969), Pasteurella pseudotuberculosis (Gonzalez-Porque \& Strominger, 1972), Phaseolus vulgaris (Liao \& Barber, 1972), and porcine thyroid tissue (Broschet et al., 1985). In the synthesis of glycosyl moieties of antibiotics, thymidine $5^{\prime}$-diphosphate (TDP) glucose 4,6-dehydratase (TDPGDH; EC 4.2.1 .46) catalyses the conversion of TDP-D-glucose to TDP-D-4-keto6-deoxyglucose (Matern et al., 1973; Grisebach, 1978; Snipes et al., 1979; Vara \& Hutchinson, 1988). It has 


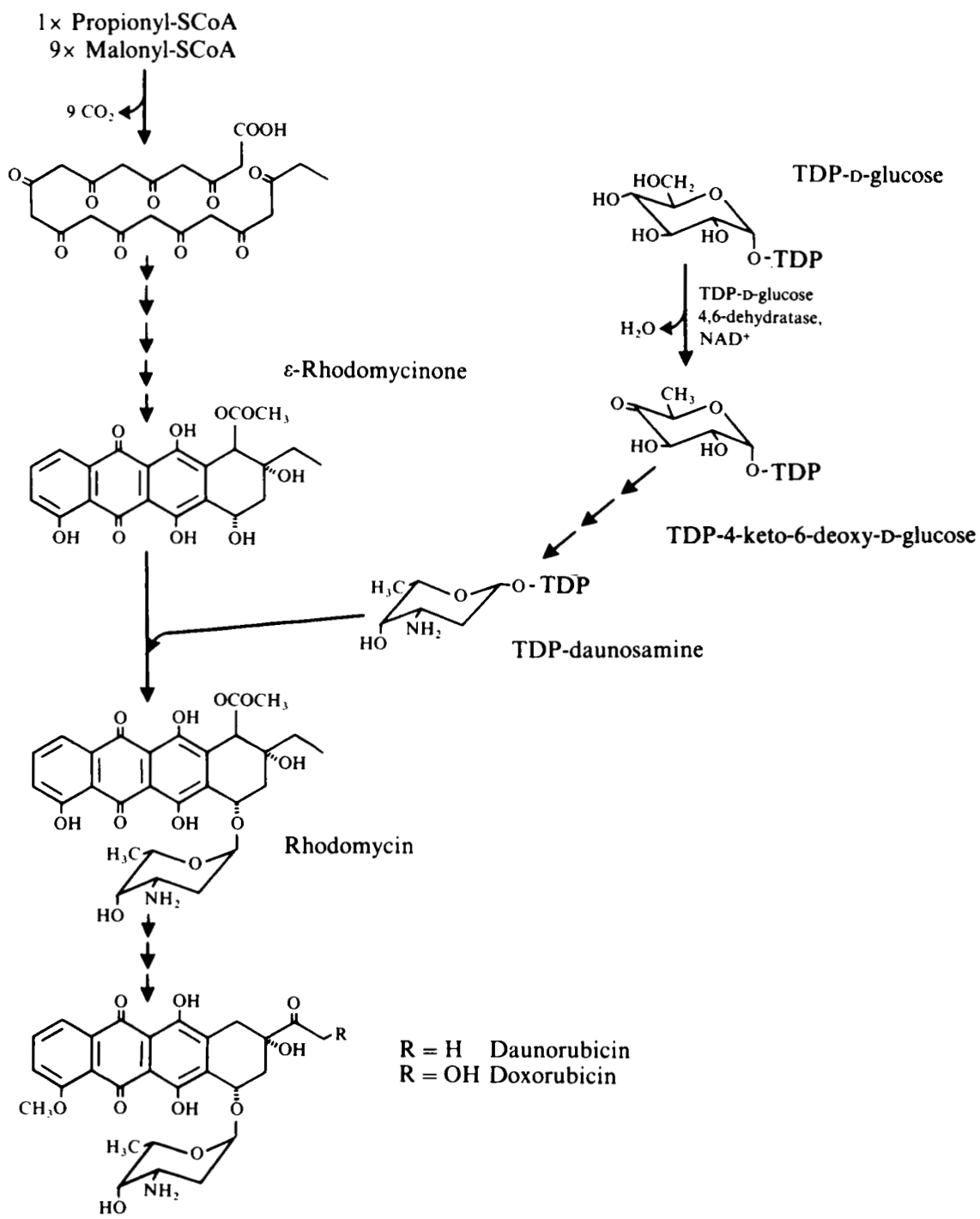

Fig. 1. Abbreviated hypothetical pathway for the biosynthesis of daunorubicin from TDP-D-glucose, acetyl-CoA, and propionyl-CoA Aglycone formation and the predicted glycosylation step for this hypothetical pathway are described in greater detail by Strohl $e t a l$. (1989) and Bartel et al. (1990).

been detected and partially purified from a tylosinproducer, Streptomyces rimosus (Matern et al., 1973), and its activity has been correlated with antibiotic biosynthesis in the chlorothricin-producer $S$. antibioticus Tü99, the granaticin producer $S$. violaceoruber Tü22 and the daunorubicin-producer Streptomyces peucetius ATCC 29050 (K. Goeke \& H. G. Floss, unpublished results). Recently, TDPGDH was purified to homogeneity from the erythromycin-producing organism, Saccharopolyspora erythraea (formerly Streptomyces erythreus) (Vara \& Hutchinson, 1988).

Doxorubicin, and its 14-deoxy analogue, daunorubicin, are the major anthracyclines used clinically in the United States for the treatment of neoplasias including breast, bladder, lung, ovarian, and thyroid cancers, osteogenic sarcoma, neuroblastomas, Hodgkin's disease and other lymphomas, and acute leukaemias (Crooke, 1981). The 2,3,6-trideoxy-3-amino hexose, daunosamine (Fig. 1), at C-7 of the anthracyclinone moiety is required for the antineoplastic activity of doxorubicin and daunorubicin (Fujiwara \& Hoshino, 1983). Although little is known about the biosynthesis of TDP-daunosamine in anthracycline-producing streptomycetes, it seems likely that the first committed step would be the conversion of TDPD-glucose to TDP-D-4-keto-6-deoxyglucose catalysed by TDPGDH (Fig. 1). In this study, TDPGDH was purified to near-homogeneity from the baumycin and daunorubicin-producing strain Streptomyces sp. C5, and from the daunorubicin-producing strain $S$. peucetius ATCC 29050. 


\section{Methods}

Organisms and fermentation conditions. Streptomyces sp. C5 (Bartel et al., 1990; Strohl et al., 1989) was from the Frederick Cancer Research Center, Frederick, MD, and Streptomyces peucetius (Dekleva et al., 1985; Strohl et al., 1989) was obtained as ATCC 29050 from the American Type Culture Collection, Rockville, MD.

Spores scraped from plates of R2YE agar medium (Hopwood et al., 1985) were used to inoculate eight $250 \mathrm{ml}$ baffled culture flasks containing seed medium, which contained (per litre): malt extract, $10 \mathrm{~g}$; glucose, $10 \mathrm{~g}$; peptone, $5 \mathrm{~g}$; and yeast extract, $4 \mathrm{~g}(\mathrm{pH} \mathrm{7.0,}$ adjusted with $\mathrm{NaOH}$ before autoclaving). Seed cultures were incubated for $3 \mathrm{~d}$ with rotary shaking $\left(250 \mathrm{r}\right.$.p.m.) at $30^{\circ} \mathrm{C}$ and then were used to inoculate (inoculum size, 9-10\%,v/v) stirred-tank fermenters containing NDYE medium, which consisted of (per litre): glucose, $22.5 \mathrm{~g}$; yeast extract, $5 \mathrm{~g} ; \mathrm{NaNO}_{3}, 4 \cdot 28 \mathrm{~g} ; 3$-( $\mathrm{N}$-morpholino)propane sulphonate (MOPS), $4.18 \mathrm{~g} ; \mathrm{K}_{2} \mathrm{HPO}_{4}, 0 \cdot 174 \mathrm{~g}$; and $10 \times$ trace element solution (Dekleva \& Strohl, 1987), $2 \mathrm{ml}$. In $S$. peucetius fermentations, maltose was substituted for glucose in both seed and production media to prevent acidogenesis (Dekleva \& Strohl, 1987).

Preliminary fermentations, in which TDPGDH activity was determined as a function of time, biomass accumulation and antibiotic production, were run for $5 \mathrm{~d}$ using fermenters $(141,101$ working volume) as previously described (Dekleva \& Strohl, 1988). Dry weights and total anthracycline production were analysed as described by Dekleva et al. (1985).

For purification of TDPGDH, cultures were grown in a (24l, 201 working volume) New Brunswick CMF $128 \mathrm{~S}$ fermenter under the following conditions: air flow, $101 \mathrm{~min}^{-1}$; agitation, 250 r.p.m.; temperature, $30^{\circ} \mathrm{C}$; the $\mathrm{pH}$, initially 7.0 , was not controlled. Streptomyces sp. C5 mycelia were harvested after $36 \mathrm{~h}$ of growth using a Pellicon tangential flow filtration apparatus (Millipore) followed by centrifugation at $16000 \mathrm{~g}$ for $30 \mathrm{~min}\left(4^{\circ} \mathrm{C}\right)$. S. peucetius mycelia were harvested after $120 \mathrm{~h}$ of growth by centrifugation at $16000 \mathrm{~g}$ for $30 \mathrm{~min}$ $\left(4^{\circ} \mathrm{C}\right)$.

Purification of TDPGDH. Streptomyces sp. C5 (101 g of frozen mycelial paste) was disrupted with an automated French press (American Instrument Co.) at $15000-16000$ p.s.i. in $200 \mathrm{ml} 0.05 \mathrm{M}$ Tris/ $\mathrm{HCl}$ buffer (pH 7.8) containing $5 \mathrm{~mm}$-dithiothreitol (DTT), $5 \%$ (w/v) glycerol, $1 \mathrm{~mm}$-EDTA, and protease inhibitors [1 mM-pepstatin A, $0 \cdot 1 \mu \mathrm{M}$-leupeptin, and $0 \cdot 1 \mu \mathrm{M}$-phenylmethylsulphonyl fluoride (PMSF)]. For purification of TDPGDH from $S$. peucetius, $98 \mathrm{~g}$ frozen mycelial paste was used.

All enzyme purification procedures were carried out at $4{ }^{\circ} \mathrm{C}$ and all buffers, including those used for equilibration and elution, contained $5 \%$ (w/v) glycerol, 5 mM-DTT, and 1 mM-EDTA. Unbroken mycelia and cell walls were pelleted by centrifugation at $39000 \mathrm{~g}$ for $20 \mathrm{~min}$. DNA and some proteins were precipitated from the supernatant by addition of streptomycin sulphate to a final concentration of $1 \%(w / v)$. After additional centrifugation at $39000 \mathrm{~g}$ as above, the supernatant was chromatographed on a DEAE-Sepharose column $(10 \times 5 \mathrm{~cm})$ which had been equilibrated with $0.05 \mathrm{M}$-Tris/ $\mathrm{HCl}(\mathrm{pH} 7.8)$. After sample application, the column was washed with $100 \mathrm{ml}$ equilibration buffer; then the enzyme was eluted with a linear gradient of 0 to $0.5 \mathrm{M}$ $\mathrm{KCl}$ in $0.05 \mathrm{M}$-Tris/ $\mathrm{HCl}$ buffer ( $\mathrm{pH} \mathrm{7.8).} \mathrm{The} \mathrm{enzyme-containing}$ fractions were combined and concentrated by precipitation with ammonium sulphate $\left(65 \%\right.$ of saturation; $\left.5{ }^{\circ} \mathrm{C}\right)$. The pellet was resuspended in $2 \mathrm{ml}$ of $0.05 \mathrm{M}-\mathrm{Tris} / \mathrm{HCl}(\mathrm{pH} 7.8)$ containing $0.1 \mathrm{M}-\mathrm{KCl}$ and the soluble proteins were size-fractionated through a Sephadex G-200 gel-filtration column $(150 \times 1 \mathrm{~cm})$ using $0.05 \mathrm{M}-\mathrm{Tris} / \mathrm{HCl}$ (pH 7.8) containing $0.1 \mathrm{M} \cdot \mathrm{KCl}$ as the elution buffer. The TDPGDH was then concentrated using a Centriprep 10 ultrafiltration system (Amicon) and exchanged into $0.05 \mathrm{M}-\mathrm{KH}_{2} \mathrm{PO}_{4}-\mathrm{K}_{2} \mathrm{HPO}_{4}$ buffer (pH 7.8; PPB). The enzyme was then loaded on a Mono $Q$ column that had been equilibrated with 0.05 M-PPB (pH 7.8), washed with equilibration buffer, and eluted from the column with a $60 \mathrm{ml}$ linear gradient of 0 to $1.0 \mathrm{M}-\mathrm{KCl}$ in $0.05 \mathrm{M}-\mathrm{PPB}(\mathrm{pH} 7.8)$ essentially as described by Vara \& Hutchinson (1988). The flow rate was maintained at $2 \mathrm{ml} \mathrm{min}-1$ and protein peaks were detected by absorbance at $280 \mathrm{~nm}$. TDPGDH obtained from the Mono $\mathrm{Q}$ column was concentrated using a Centriprep 10 as above and loaded on a Progel-TSK 3000 SWXL (Supelco) gel-filtration HPLC column. The enzyme was separated from contaminating proteins by HPLC gel-filtration using a mobile phase of $0.05 \mathrm{M}-\mathrm{PPB}(\mathrm{pH} 7.5$ ) containing $0.1 \mathrm{M}-\mathrm{KCl}$. An Altex model 100A HPLC and an Altex model 100-40 flow-through cell in a Hitachi spectrophotometer set to $280 \mathrm{~nm}$ were used for HPLC analyses. Chromatographic separations were recorded with a HewlettPackard model 3390A integrator.

Polyacrylamide gel electrophoresis. SDS-PAGE used a $12 \%(\mathrm{w} / \mathrm{v})$ resolving gel and a $3 \%(w / v)$ stacking gel (O'Farrell, 1975). The final concentration of SDS in both gels was $0.1 \%$. Samples were prepared by mixing $15-20 \mu \mathrm{g}$ of protein in a buffer containing $60 \mathrm{mM}-\mathrm{Tris} / \mathrm{HCl}$ (pH 6.8), $5 \%$ (v/v) $\beta$-mercaptoethanol, $10 \%(\mathrm{w} / \mathrm{v})$ glycerol, $0.1 \%$ SDS, and a few crystals of bromophenol blue. Electrophoresis was run at 15-20 mA per gel. Protein in the gels was detected using silver nitrate as described by Merrill et al. (1983).

Measurement of TDPGDH activity. TDPGDH activity was measured spectrophotometrically in a $107.5 \mu$ l enzymic reaction mixture containing $50 \mathrm{~mm}$-Tris/ $\mathrm{HCl}$ (pH 7.5), $1 \mathrm{mM}-\mathrm{NAD}^{+}, 1 \mathrm{~mm}$-TDP-D-glucose, and approx. 0.03 to 0.06 units TDPGDH. The reaction mixture was incubated at $37^{\circ} \mathrm{C}$ for $1 \mathrm{~h}$, after which $75 \mu \mathrm{l}$ of $100 \mathrm{~mm}-\mathrm{NaOH}$ was added. This mixture was incubated for $15 \mathrm{~min}$, after which $A_{320}$ was recorded using a Bausch and Lomb Spectronic 2000. The molar absorption coefficient at $320 \mathrm{~nm}$ used to calculate the amount of TDPD-4-keto-6-deoxyglucose formed was $45001 \mathrm{~mol}^{-1} \mathrm{~cm}^{-1}$ (Matsuhashi \& Strominger, 1966). It should be noted that Wang \& Gabriel (1969) used $48001 \mathrm{~mol}^{-1} \mathrm{~cm}^{-1}$, and Vara \& Hutchinson (1988) and Zarkjowsky \& Glaser (1969), $65001 \mathrm{~mol}^{-1} \mathrm{~cm}^{-1}$ as the molar absorption coefficients for this reaction. One unit of enzyme activity is defined as the amount of enzyme required to form 1 nmol TDP-D-4-keto6-deoxyglucose per min under the described assay conditions. Protein was measured by the dye binding assay of Bradford (1976) using reagent purchased from BioRad.

Analysis of the enzyme reaction product. The product from the reaction between TDP-[U-14 $\mathrm{C}]-\mathrm{D}-\mathrm{glucose}(2 \mu \mathrm{Ci} ; 0.6 \mathrm{~mm})$ and $\mathrm{NAD}^{+}$, catalysed by purified TDPGDH, was separated from the reactant by thin-layer chromatography (TLC) on cellulose plates (Brinkman MN-300) using isobutyric acid/1 $\mathrm{M}$-ammonium hydroxide $(1 \cdot 0: 0 \cdot 6)$ as the developing solvent. Radioactive nucleotide hexoses were detected by autoradiography using XAR-5 (Kodak) X-ray film, scraped from the plates into $50 \mu \mathrm{lddH} \mathrm{H}_{2} \mathrm{O}$, and reduced by treatment for $2 \mathrm{~h}$ with $50 \mu \mathrm{l} \mathrm{NaBH}$ $\left(10 \mathrm{mg} \mathrm{ml}^{-1}\right.$ in $\left.20 \mathrm{~mm}-\mathrm{NaOH}\right)$. The sugar nucleotides were then hydrolysed for $4 \mathrm{~h}$ at $37^{\circ} \mathrm{C}$ with $0.14 \mathrm{U}$ of snake venom phosphodiesterase and $0.35 \mathrm{U}$ of alkaline phosphatase in $0.05 \mathrm{M}$-Tris/ $\mathrm{HCl}$ (pH 9.4). Protein was precipitated from the mixture by heating for 5 min at $90^{\circ} \mathrm{C}$ and removed by centrifugation. The solution containing the hexose products was lyophilized, resuspended in $20 \mu \mathrm{ddd} \mathrm{H}_{2} \mathrm{O}$, and chromatographed (TLC) on silica gel with chloroform/methanol $(6: 4)$ as the mobile phase. Hexoses were detected by silver staining (Trevelyan et al., 1950). Non-radioactive reaction products separated by cellulose TLC were also examined by fast atom bombardment mass spectroscopy (FAB-MS) using a VG-70-250S FAB mass spectrometer.

Kinetics and substrate and inhibitor specificity of TDPGDH. $K_{\mathrm{m}}^{\prime}$ and $V_{\max }^{\prime}$ were determined in triplicate for $\mathrm{NAD}^{+}$and TDP-D-glucose from Lineweaver-Burk double reciprocal plots of enzyme reactions with a range of $\mathrm{NAD}^{+}$and TDP-D-glucose concentrations. For the kinetics as a function of $\mathrm{NAD}^{+}$concentration, TDP-D-glucose was in excess 
$(1 \mathrm{mM})$ and the concentration of $\mathrm{NAD}^{+}$varied from 10 to $250 \mu \mathrm{M}$. For the kinetics as a function of TDP-D-glucose concentration, NAD ${ }^{+}$was in excess $(1 \mathrm{mM})$ and the concentration of TDP-D-glucose varied from 25 to $250 \mu \mathrm{M}$. The kinetic constants for $\mathrm{NAD}^{+}$and TDPD-glucose were calculated using the enzyme kinetic model fitting software EZ-FIT (Perella Scientific). This software program fits experimental data to enzyme kinetic models using the Nelder-Mead Simplex and Marquardt nonlinear regression methods.

Inhibition reactions were carried out in triplicate using $2 \mathrm{mM}$ inhibitor (TTP, TDP, or TMP). Alternative substrates (ADP-glucose, ADP-mannose, CDP-glucose, GDP-glucose, GDP-mannose, UDPglucose, or UDP-galactose) were used at $1 \mathrm{mM}$.

$N$-terminal sequencing of TDPGDH. Purified TDPGDH was adsorbed on a pre-wetted polyvinylidene difluoride (PVDF) membrane during overnight incubation in distilled water with excised SDS-PAGE gel plugs. The $\mathrm{N}$-terminal amino acid sequences of the purified enzyme from Streptomyces sp. C5 (10 pmol), and of the protein bands (15 pmol each) from $S$. peucetius thought to be the monomeric subunits of TDPGDH, were determined by Edman degradation using an automated gas-phase protein sequencer (Model 470A; Applied Biosystems) and an on-line phenylthiohydantoin (PTH) analyser (Model 120A; Applied Biosystems).

Reproducibility of results. Unless otherwise stated, all experiments were carried out at least in triplicate and the results given are the averages of those data. For purifications, all steps except the final gel filtration by HPLC (which was performed only once) were performed at least four times and the data given are for representative runs.

\section{Results and Discussion}

\section{Fermentation of Streptomyces sp. C5 and S. peucetius}

In Streptomyces sp. C5 fermentations, TDPGDH specific activity peaked between 24 and $42 \mathrm{~h}$. The maximum rate of anthracycline production by Streptomyces sp. C5 was between 24 and $48 \mathrm{~h}$ (data not shown). On the other hand, in $S$. peucetius fermentations, the specific activity of TDPGDH remained constant between 48 and $120 \mathrm{~h}$, during which period anthracyclines were continuously produced (data not shown). Thus, in both cases, the specific activity of TDPGDH correlated with anthracycline production, supporting a role for this enzyme in the biosynthesis of the daunosamine moiety.

\section{Purification of TDPGDH from Streptomyces sp. C5}

Streptomycin sulphate precipitated $120 \%$ of the TDPGDH activity in crude extracts. In preliminary experiments, the total activity precipitated was often 2 to 3-fold that in the crude enzyme fraction, suggesting that either an inhibitor of TDPGDH or an enzyme consuming the TDPGDH product had been removed.

TDPGDH activity was eluted from DEAE-Sepharose at $0.28-0.32 \mathrm{M}-\mathrm{KCl}$ (Fig. $2 a$ ) with a 6.5 -fold purification (Table 1). Precipitation of the active fractions with ammonium sulphate and fractionation by gel-filtration
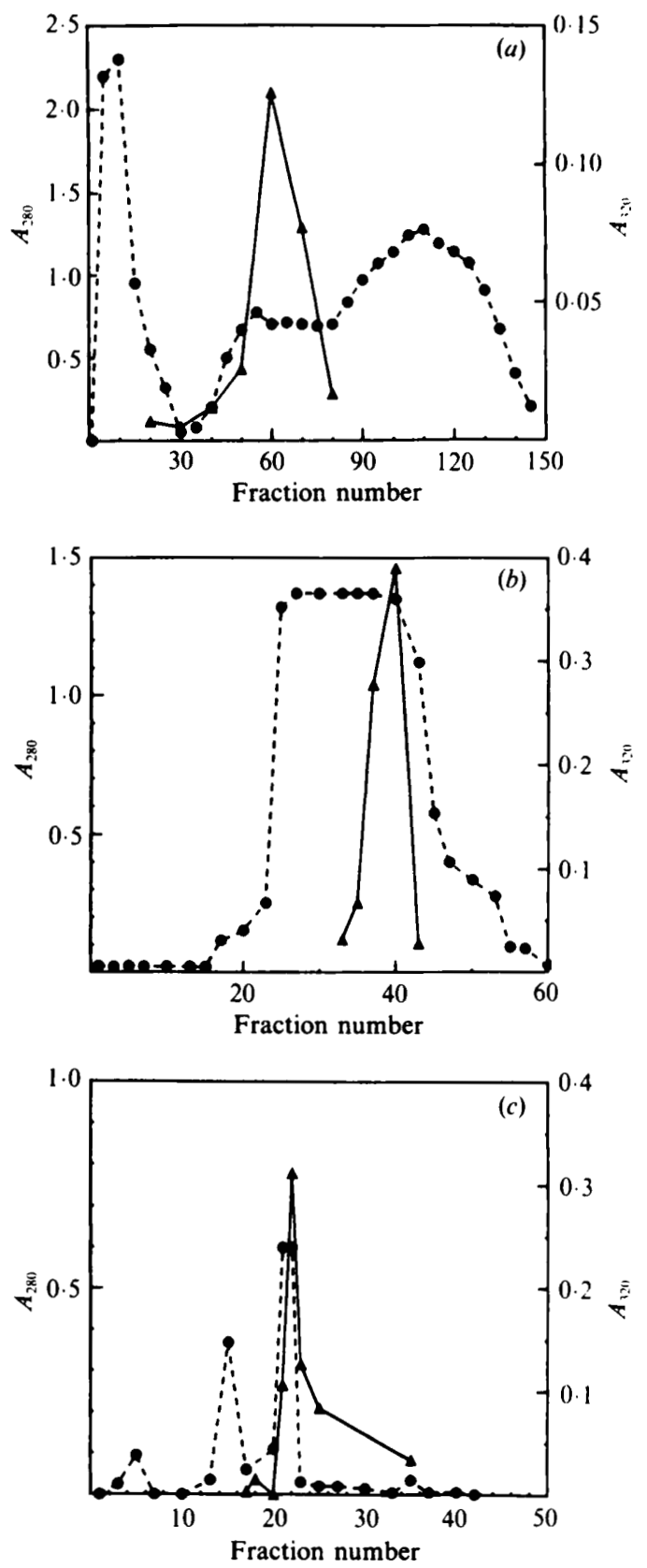

Fig. 2. Chromatographic steps used in the purification of TDPGDH from Streptomyces sp. C5. For each step, protein $(\bullet)$ and enzyme activity (A) were measured as described in Methods. (a) DEAESepharose ion-exchange chromatography profile; the enzyme was eluted at 0.28 to $0.32 \mathrm{M}-\mathrm{KCl}$. (b) Sepharose G-200 gel-filtration chromatography profile; the enzyme was eluted from the column at 99-129 ml. (c) Mono Q FPLC ion-exchange chromatography profile; the enzyme was eluted from the column at $0.36 \mathrm{M}-\mathrm{KCl}$ in phosphate buffer (PPB).

chromatography gave a single peak (Fig. $2 b$ ) with an additional purification of approx. 6-fold (Table 1). TDPGDH was further purified by FPLC on Mono Q using a linear gradient of 0 to $1.0 \mathrm{M}-\mathrm{KCl}$ in $0.05 \mathrm{M}-\mathrm{PPB}$ (pH 7.8). The enzyme eluted in a single, sharp peak at 
Table 1. Scheme for purification of TDPGDH from Streptomyces sp. C5

All steps were carried out at least four times except the final TSK-3000 step which was done once. The data shown are from a representative purification run.

\begin{tabular}{|c|c|c|c|c|c|}
\hline Purification step & $\begin{array}{l}\text { Protein } \\
\text { (mg) }\end{array}$ & $\begin{array}{l}\text { Total activity } \\
\left(\text { nmol } \text { min }^{-1}\right)\end{array}$ & $\begin{array}{c}\text { Specific activity } \\
{\left[\mathrm{nmol} \min ^{-1}(\mathrm{mg} \text { protein })^{-1}\right]}\end{array}$ & $\begin{array}{l}\text { Purification } \\
\text { factor }\end{array}$ & $\begin{array}{c}\text { Recovery } \\
(\%)\end{array}$ \\
\hline Crude extract & 866 & 270 & 0.31 & 1.0 & 100 \\
\hline Streptomycin sulphate & 624 & 324 & 0.52 & 1.7 & 120 \\
\hline DEAE-Sepharose & 81 & 280 & 3.46 & 11 & 104 \\
\hline Sephadex G-200 & 13 & 264 & $20 \cdot 3$ & 65 & 98 \\
\hline Mono Q FPLC & 0.41 & 100 & 244 & 787 & 37 \\
\hline TSK-3000 HPLC & $0 \cdot 37$ & 111 & 300 & 968 & 41 \\
\hline
\end{tabular}

$0.36 \mathrm{M}-\mathrm{KCl}$ (Fig. $2 c$ ). This step resulted in a $2 \cdot 6$-fold loss of enzyme activity but achieved a purification of approx. 12-fold (Table 1). Pure TDPGDH was obtained by highperformance liquid chromatography (HPLC) on a Progel-TSK 3000SWXL gel-filtration column. The

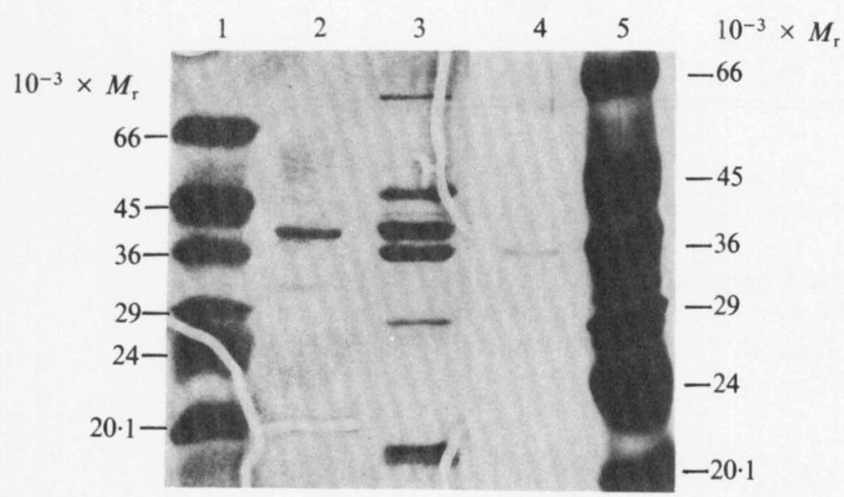

Fig. 3. Determination of $M_{\mathrm{r}}$ for the polypeptide subunits of the TDPGDH enzymes from Streptomyces sp. C5 and $S$. peucetius ATCC 29050 by SDS-PAGE analysis. Lanes 1 and 5, SDS-PAGE standards; bovine serum albumin (66000), egg albumin (45000), subunit of glyceraldehyde 3-phosphate dehydrogenase $(36000)$, carbonic anhydrase (29000), trypsinogen (24000), trypsin inhibitor (20100), and $\alpha$-lactalbumin (14200). Lane 2, subunit of purified TDPGDH from Streptomyces sp. C5 after chromatography through the HPLC gelfiltration step, calculated to have a $M_{\mathrm{r}}$ of 39000 . Lane 3, peptides still present in preparation of TDPGDH from $S$. peucetius after chromatography through the HPLC gel-filtration step. Lane 4, peptide presumed to be the monomer of TDPGDH from S. peucetius which was eluted from the gel at the stage indicated in Lane 3 and sequenced (see Fig. 4). This peptide was calculated to have a $M_{\mathrm{r}}$ of 36000 . The data shown in lanes 4 and 5 are from separate gels; hence, the peptides migrated slightly differently from those shown in lanes $1-3$. retention time of the enzyme $(17.45 \mathrm{~min})$ indicated a $M_{\mathrm{r}}$ of approx. 74000 (data not shown); the TDPGDH was purified 968-fold from the crude extract with a $41 \%$ recovery (Table 1). The $M_{\mathrm{r}}$ of the monomeric polypeptide subunit given by SDS-PAGE was 39000 (Fig. 3). Since SDS-PAGE analysis is more precise than gelfiltration, the native enzyme is presumed to be a homodimer of $M_{\mathrm{r}}=78000$ containing monomeric subunits of $M_{\mathrm{r}}=39000$.

\section{Purification of TDPGDH from S. peucetius ATCC 29050}

The same purification protocol as described above was used to purify TDPGDH from $S$. peucetius cell extracts (data not shown). S. peucetius TDPGDH eluted from the HPLC gel-filtration column at a retention time of $17.6 \mathrm{~min}$, giving a $M_{\mathrm{r}}$ of 68000 for the native protein. After the HPLC gel-filtration step, the TDPGDH from $S$. peucetius had been purified 1000 -fold over crude cellfree extract with a recovery of $37 \%$ (data not shown).

\section{$N$-terminal amino acid sequences of the purified enzyme subunits}

The sequence of the first 22 amino acids from the $\mathrm{N}$-terminus of TDPGDH from Streptomyces sp. C5 was determined (Fig. 4). The $\mathrm{N}$-terminal amino acid sequence was markedly different from that of TDPGDH in the erythromycin-producer Sac. erythraea (Fig. 4). The TDPGDH from $S$. peucetius was not purified to homogeneity; however, only a few major bands

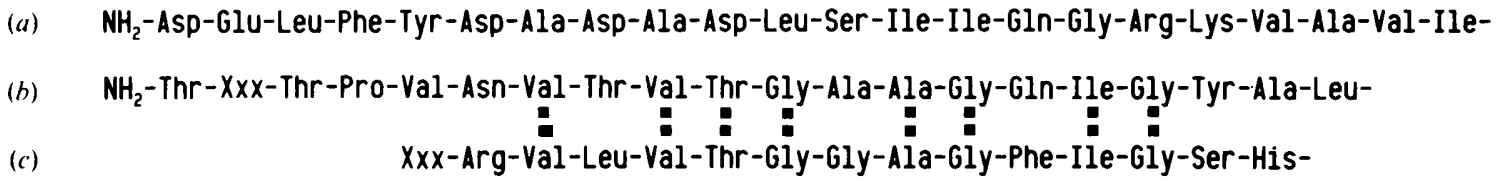

Fig. 4. The N-terminal amino acid sequence of : (a) the peptide monomer of the purified TDPGDH from Streptomyces $\mathrm{sp}$. C5; (b) the $M_{\mathrm{r}}=36000$ peptide from $S$. peucetius ATCC 29050 believed to be the monomer of TDPGDH from that organism; and (c) the TDPGDH from Sac. erythraea (Vara \& Hutchinson, 1988) (unpublished sequence data courtesy of C. R. Hutchinson) (sequence C, bottom line). The bottom two sequences are aligned for maximum conservation; conserved amino acids are indicated ( $)$. 
Table 2. Comparison of the characteristics of TDPGDH from Streptomyces sp. C5, S. peucetius, Sac. erythraea and E. coli

All experiments shown in this table were done in triplicate. The data shown are averages of the results obtained. In no cases were the data points more than $10 \%$ from the mean shown. $K_{\max }^{\prime}$ and $V_{\max }^{\prime}$ values are rounded off to integers. $V_{\max }^{\prime}$ values are given in $\mathrm{nmol} \min ^{-1}$ (mg protein $)^{-1}$. The $V_{\max }^{\prime}$ value for the $S$. peucetius enzyme on TDP-D-glucose is shown in brackets since the enzyme was only one of five major proteins in the assay mixture. Although the percent TDPGDH of total protein was calculated by scanning densitometry of the gels (data not shown), the value given is only an estimate, considering the amount of contaminating protein (see Fig. 3, lane 3).

\begin{tabular}{|c|c|c|c|c|}
\hline Characteristic & Streptomyces C5 & S. peucetius & Sac. erythraea & E. coli \\
\hline$M_{\mathrm{r}}$ of native enzyme & 78000 & 72000 & 72000 & 78000 \\
\hline$M_{\mathrm{r}}$ of subunits & 39000 & 36000 & 36000 & 39000 \\
\hline Enzyme structure & Homodimer & Homodimer & Homodimer & Homodimer \\
\hline Activity in absence of $\mathrm{NAD}^{+}$ & - & - & - & + \\
\hline Optimum $\mathrm{pH}$ for activity & $7 \cdot 6$ & $7 \cdot 8$ & $7 \cdot 5$ & $8 \cdot 0-8 \cdot 5$ \\
\hline \multicolumn{5}{|l|}{ Kinetics } \\
\hline$K_{\mathrm{m}}^{\prime}$ (TDP-D-glucose) & $31 \mu \mathrm{M}$ & $35 \mu \mathrm{M}$ & $34 \mu \mathrm{M}$ & $70 \mu \mathrm{M}$ \\
\hline$V_{\max }^{\prime}$ (TDP-D-glucose) & 309 & 201 & 433 & 7000 \\
\hline$K_{\mathrm{m}}^{\prime \prime}\left(\mathrm{NAD}^{+}\right)$ & $19 \mu \mathrm{M}$ & $20 \mu \mathrm{M}$ & $19 \mu \mathrm{M}$ & $100-200 \mu \mathrm{M}$ \\
\hline \multicolumn{5}{|l|}{ Inhibition by* } \\
\hline TTP (2 mм) & $37 \%$ & $40 \%$ & $77 \%$ & ND \\
\hline TDP (2 mM) & $62 \%$ & $58 \%$ & $90 \%$ & ND \\
\hline TMP (2 mM) & $25 \%$ & $23 \%$ & $11 \%$ & ND \\
\hline References $\dagger$ & This work & This work & $a$ & $b$ \\
\hline
\end{tabular}

ND, not determined by cited authors.

,- Catalytic amounts of $\mathrm{NAD}^{+}$required for activity.

,$+ \mathrm{NAD}^{+}$tightly bound to enzyme, removable only with thiol reagents (Wang \& Gabriel, 1969) or by acid denaturation (Vara \& Hutchinson, 1988).

* These data are averages of three determinations. For these experiments, the control $(100 \%)$ activities for the

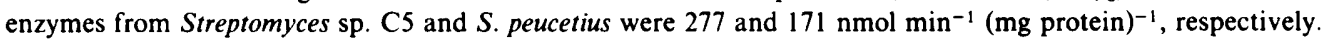

$\dagger$ References: $a$, Vara \& Hutchinson, 1988; $b$, Wang \& Gabriel, 1969, and Zarkowsky \& Glaser, 1969.

remained in the SDS-PAGE gels of the product, obtained by a purification protocol that had yielded a near-homogeneous enzyme from Streptomyces sp. C5 (Fig. 3). Attempts to remove the contaminating proteins from the final $S$. peucetius preparation, including hydrophobic chromatography, isoelectric focussing and chromatofocussing, were not successful; therefore, the two major peptides in the 30000 to $40000 M_{\mathrm{r}}$ range [the most probable size based upon the properties of TDPGDH from Streptomyces sp. C5 and Sac. erythraea (Vara \& Hutchinson, 1988) and the HPLC gel-filtration data on the $S$. peucetius enzyme] were excised from an SDS-PAGE gel and their N-terminal amino acids were sequenced. The polypeptide with $M_{\mathrm{r}} 36000$ had an $\mathrm{N}$-terminal sequence similar to that of TDPGDH from Sac. erythraea (Fig. 4). The sequence of the $M_{\mathrm{r}}=$ approx. 40000 peptide showed no similarity to those of the Streptomyces sp. C5 or Sac. erythraea TDPGDH (data not shown). From the combined HPLC gel-filtration data (which show that the $S$. peucetius enzyme is slightly smaller than that of Streptomyces sp. C5), the SDSPAGE data, and the $\mathrm{N}$-terminal amino acid sequences, the native enzyme appears to be a homodimer with a $M_{\mathrm{r}}$ of 72000 and a subunit $M_{\mathrm{r}}$ of 36000 (Table 2).

\section{Characterization of the optimal enzyme reaction conditions}

The pHs for optimum activity of TDPGDH from Streptomyces sp. C5 and S. peucetius are 7.6 and 7.8 , respectively (Table 2 ). The enzymes from $S$. rimosus (Matern et al., 1973) and Sac. erythraea (Vara \& Hutchinson, 1988) had optima at $\mathrm{pH} 7 \cdot 2$ and $7 \cdot 5$, respectively, whereas $E$. coli TDPGDH had a pH optimum in the range of 8.0-8.5 (Wang \& Gabriel, 1969; Zarkowsky \& Glaser, 1969).

Neither the Streptomyces sp. C5 nor the $S$. peucetius TDPGDH was active when either ADP-glucose, ADPmannose, CDP-glucose, GDP-glucose, GDP-mannose, UDP-glucose, or UDP-galactose was substituted for TDP-D-glucose (Table 2). The $E$. coli enzyme also did not utilize UDP-glucose as an alternative substrate but was capable of using dUDP-D-glucose, albeit with a substantially lower affinity (Zarkowsky \& Glaser, 1969).

The enzymes from both streptomycetes gave a linear increase in absorbance for $60 \mathrm{~min}$ in the presence of excess TDP-D-glucose and NAD ${ }^{+}$(data not shown). Very low enzyme activity (i.e. less than $10 \%$ of maximum) was observed for TDPGDH from both 
sources in assay mixtures lacking $\mathrm{NAD}^{+}$; a similar $\mathrm{NAD}^{+}$requirement was reported for TDPGDH from Sac. erythraea (Vara \& Hutchinson, 1988), S. rimosus (Matern et al., 1973), and Pseudomonas aeruginosa (Glaser \& Kornfeld, 1961), but in contrast, TDPGDH from $E$. coli strain B has tightly bound NAD+ (Wang \& Gabriel, 1969; Zarkowsky \& Glaser, 1969).

\section{Identification of the TDPGDH reaction product of Streptomyces sp. C5}

The product of the reaction catalysed by TDPGDH was analysed by TLC, reduction and enzymic cleavage to detect the predicted hexoses, and by FAB-MS to detect the expected TDP-D-keto-6-deoxyglucose. When TDP-[U-14 C]glucose $\left(251 \mathrm{mCi} \mathrm{mmol}^{-1}\right.$; ICN Pharmaceuticals) was incubated with $\mathrm{NAD}^{+}$and purified TDPGDH from Streptomyces sp. C5, the product formed migrated at an $R_{\text {TDP.D-glucose }}$ (i.e. mobility in relation to TDP-D-glucose) of 1.2 during TLC on cellulose. When this compound was eluted from the TLC plates and subjected to FAB-MS, it gave a molecular ion of 569, which is the expected $M+1$ for TDP-D-4-keto-6-deoxyglucose monosodium salt (data not shown). The reaction product eluted from the TLC plates was also reduced with $\mathrm{NaBH}_{4}$ and enzymically hydrolysed; the two products co-migrated on silica gel TLC plates with authentic quinovose (6-deoxy-D-glucose) and fucose (6-deoxy-D-galactose) (data not shown), which are the expected products of the non-stereospecific reduction and hydrolysis of TDP-D-4-keto-6-deoxyglucose (Glaser \& Kornfeld, 1961). The product formed by the partially purified TDPGDH from $S$. peucetius had the same $R_{F}$ value as the product of the Streptomyces sp. C5 enzymic reaction.

\section{Kinetics of TDPGDH activity from Streptomyces sp. C5 and $S$. peucetius}

$K_{\mathrm{m}}^{\prime}$ and $V_{\max }^{\prime}$ values for TDPGDH from Streptomyces sp. $\mathrm{C} 5$ and $S$. peucetius are shown in Table 2 . The $K_{\mathrm{m}}^{\prime}$ values for TDP-D-glucose of TDPGDH from $S$. peucetius, Streptomyces sp. C5 and Sac. erythraea are all approx. 31-35 $\mu \mathrm{M}$, whereas for the $E$. coli enzyme the $K_{\mathrm{m}}^{\prime}$ is $70 \mu \mathrm{M}$ (Wang \& Gabriel, 1969; Zarkowsky \& Glaser, 1969). The partially purified TDPGDH from the tylosinproducing strain, $S$. rimosus, had a $K_{\mathrm{m}}^{\prime}$ for TDPD-glucose of $93 \mu \mathrm{M}$ (Matern et al., 1973). With $\mathrm{NAD}^{+}$as substrate, the $K_{\mathrm{m}}^{\prime}$ values for the streptomycete enzymes were 19-20 $\mu \mathrm{M}$, a range approx. 5-10 fold lower than for the $E$. coli enzyme (Table 2).

\section{Inhibition of TDPGDH by nucleotides}

Inhibition was determined by including thymidine 5 '-triphosphate (TTP), TDP, or thymidine 5'-monophosphate (TMP), and TDP-D-glucose in enzyme mixtures. TDP had the greatest effect, inhibiting enzyme activity from both organisms (Table 2). With 2 mM-TDP, Streptomyces sp. C5 and $S$. peucetius TDPGDH activities were only $38 \%$ and $42 \%$ of the value for the control.

\section{Involvement of TDPGDH in daunosamine biosynthesis}

The enzymes from Streptomyces sp. C5 and S. peucetius were optimally active during peak anthracycline production, not during exponential growth as would be expected for enzymes of primary metabolism (Dekleva \& Strohl, 1988). This suggests that these enzymes participate in daunosamine biosynthesis rather than in the synthesis of a growth constituent such as the cell wall. Moreover, only a single TDPGDH activity was detected in the extracts of each organism (M. W. Thompson, unpublished results). Interestingly, the specific activities of TDPGDH in crude extracts of both Streptomyces sp. $\mathrm{C} 5$ and $S$. peucetius were in the same range as the specific activity of aklanonic acid methyltransferase, an enzyme of anthracyclinone formation ( $N$. C. Connors, M. Dickens \& W. R. Strohl, unpublished data). In vitro reactions in which mycelial extract of Streptomyces sp. $\mathrm{C} 5$ was incubated for $3 \mathrm{~h}$ at $37^{\circ} \mathrm{C}$ with a reaction mixture containing $48 \mathrm{mM}-\mathrm{Tris} / \mathrm{HCl}$ (pH 7.6), TDP-[U-14 C]glucose $(2 \mu \mathrm{Ci} ; 0.6 \mathrm{~mm}), 0.6 \mathrm{~mm}-\mathrm{NAD}^{+}, 0.72 \mathrm{~mm}-\mathrm{NADPH}$, $3.4 \mathrm{~mm}-\mathrm{L}$-glutamate, and $3 \mu \mathrm{g}$ pyridoxylamine phosphate $\mathrm{ml}^{-1}$ resulted in the formation of a TDP-sugar that, when reduced and hydrolysed with snake venom phosphodiesterase, co-migrated with authentic daunosamine (M. W. Thompson, unpublished results). This suggests that TDP-D-glucose can be converted to TDP-daunosamine by Streptomyces sp. C5 mycelial extracts, which further suggests that the TDP-sugar is the nucleotide form of sugar used in daunosamine formation. Studies are now being carried out to determine the possible genetic linkage of the genes encoding TDPGDH of $S$. peucetius and Streptomyces sp. C5 with genes encoding anthracycline formation.

\footnotetext{
We are indebted to Prof. C. Richard Hutchinson for supplying us with the unpublished $\mathrm{N}$-terminal amino acid sequence of the Sac. erythraea TDPGDH, to Jane Tolley of the Ohio State University Biochemistry Instrumentation Center for N-terminal amino acid sequences of the enzymes studied here, to David Chang of the Ohio State Chemical Instrumentation Center for running the FAB-MS analyses, and to Donald Ordaz at the Ohio State Fermentation Facility for assistance with the fermentations.

These studies were supported in part by Public Health Service grants GM-34387 and GM-43345 from the National Institutes of Health.
} 


\section{References}

Bartel, P. L., Connors, N. C. \& Strohl, W. R. (1990). Biosynthesis of anthracyclines: analysis of mutants of Streptomyces sp. strain C5 blocked in daunomycin biosynthesis. Journal of General Microbiology 136, 1877-1886.

BRADFORD, M. M. (1976). A rapid and sensitive method for quantitation of microgram quantities of protein utilizing the principle of protein-dye binding. Analytical Biochemistry $\mathbf{7 2}$ 248-254

Broschet, K. O., Chang, S. \& Serif, G. (1985). Purification and characterization of GDP-D-mannose 4,6-dehydratase from porcine thyroid. European Journal of Biochemistry 153, 397-401.

CROOKE, S. T. (1981). The anthracyclines. In Cancer and Chemotherapy, Vol. III. Antineoplastic agents, pp. 111-132. Edited by S. T. Crooke \& A. W. Prestayko. New York: Academic Press.

Dekleva, M. L. \& StroHL, W. R. (1987). Glucose-stimulated acidogenesis by Streptomyces peucetius. Canadian Journal of Microbiology 33, 1129-1132.

Dekleva, M. L. \& Strohl, W. R. (1988). Activity of phosphoenolpyruvate carboxylase of an anthracycline-producing streptomycete. Canadian Journal of Microbiology 34, 1241-1246.

Dekleva, M. L., Titus, J. A. \& STroHL, W. R. (1985). Nutrient effects on anthracycline production by Streptomyces peucetius in a defined medium. Canadian Journal of Microbiology 31, 287-294.

Fujiwara, A. \& Hoshino, T. (1983). Anthracycline antibiotics. Critical Reviews in Biotechnology 3, 133-157.

GABRIEL, O. (1973). Biological mechanisms involved in the formation of deoxy sugars. Enzymatic hydrogen mediation. A possible example for the evolutionary process of enzyme catalysis. In Carbohydrates in Solution, Advances in Chemistry Series No. 117, pp. 387-410. Washington, DC: American Chemical Society.

Glaser, L. \& KORNFELD, S. (1961). The enzymatic synthesis of thymidine-linked sugars. II. Thymidine diphosphate L-rhamnose. Journal of Biological Chemistry 236, 1795-1799.

Gonzalez-Porque, P. \& Strominger, J. L. (1972). Enzymatic synthesis of cytidine diphosphate 3,6-dideoxyhexoses. VI. Purification to homogeneity and some properties of cytidine diphosphateD-glucose oxidoreductase, enzyme $E_{1}$ and enzyme $E_{3}$. Journal of Biological Chemistry 247, 6748-6756.

GRISEBACH, H. (1978). Biosynthesis of sugar components of antibiotic substances. Advances in Carbohydrates Chemistry and Biochemistry $35,81-126$.

Hopwood, D. A., Bibb, M. J., Chater, K. F., Kieser, T., Bruton, C. J., Kieser, H. M., Lydiate, D. J., Smith, C. P., Ward, J. M. \&

SCHREMPF, H. (1985). Genetic Manipulation of Streptomyces - a Laboratory Manual. Norwich: John Innes Foundation.

LiaO, T.-H. \& Barber, G. A. (1972). Purification of guanosine 5'-diphosphate D-mannose oxidoreductase from Phaseolus vulgaris. Biochimica et Biophysica Acta 276, 85-93.

Matern, H., Brillinger, G. U. \& PaPe, H. (1973). Stoffwechselprodukte von Mikroorganismen. 114. Mitteilung. Thymidin-diphospho-D-glucose-oxidoreduktase aus Streptomyces rimosus. Archiv für Mikrobiologie 88, 37-48.

Matsuhashi, M. \& Strominger, J. L. (1966). Formation of TDP4-acetamido-4,6-dideoxyhexoses from TDP-D-glucose. Methods in Enzymology 8, 317-323.

Merrill, C. R., Goldman, D. \& Van Keuren, M. L. (1983). Silver staining methods for polyacrylamide gel electrophoresis. Methods in Enzymology 96, 230-239.

O'FARRELL, P. H. (1975). High resolution two-dimensional electrophoresis of proteins. Journal of Biological Chemistry 250, 4007-4021.

Schulman, M. D., Acton, S. L., Valentino, D. L. \& ARison, B. H. (1990). Purification and identification of dTDP-oleandrose, the precursor of the oleandrose units of the avermectins. Journal of Biological Chemistry 265, 16965-16970.

SNipes, C. E., Chang, C.-J. \& Floss, H. G. (1979). Biosynthesis of the antibiotic granaticin. Journal of the American Chemical Society 101, 701-706.

Strohl, W. R., Bartel, P. L., Connors, N. C., Zhu, C.-B., Dosch, D. C., Beale, J. M., JR, Floss, H. G., Stutzman-Engwall, K., OTTEN, S. L. \& HUTCHINSON, C. R. (1989). Biosynthesis of natural and hybrid polyketides by anthracycline-producing streptomycetes. In Genetics and Molecular Biology of Industrial Microorganisms, pp. 68-84. Edited by C. L. Hershberger, S. W. Queener and G. Hegeman. Washington, DC: American Society for Microbiology.

Trevelyan, W. E., Proctor, D. P. \& Harrison, J. S. (1950). Detection of sugars on paper chromatograms. Nature, London 166, 443-444.

VARA, J. A. \& Hutchinson, C. R. (1988). Purification of thymidinediphospho-D-glucose 4,6-dehydratase from an erythromycin-producing strain of Saccharopolyspora erythraea by high resolution liquid chromatography. Journal of Biological Chemistry 263, 14992-14995.

WANG, S.-F. \& GABRIEL, O. (1969). Biological mechanisms involved in the formation of deoxy sugars. V. Isolation and crystallization of thymidine diphosphate-D-glucose oxidoreductase from Escherichia coli B. Journal of Biological Chemistry 244, 3430-3437.

ZARKOWSKY, H. \& Glaser, L. (1969). The mechanism of 6-deoxyhexose synthesis. III. Purification of deoxythymidine diphosphateglucose oxidoreductase. Journal of Biological Chemistry 244, $4750-4756$. 